\title{
Thyroxine and Triiodothyronine Metabolism in Maternal and Fetal Sheep
}

\author{
D. A. Fisher ${ }^{[21]}$, J. H. Dussault, A. Erenberg, and R. W. Lam \\ Division of Endocrinology, Harbor General Hospital, Torrance, California and Department of Pediatrics, \\ University of California at Los Angeles, Los Angeles, California, USA
}

\begin{abstract}
Extract
Kinetic studies of thyroxine (T4) and triiodothyronine (T3) and measurements of hormone turnover were conducted in chronically catheterized maternal and fetal sheep during the last trimester of gestation. Mean serum total T4 and free T4 (FT4) concentrations were higher in fetal than in maternal serum ( 7.5 versus 5.4 $\mu \mathrm{g} / 100 \mathrm{ml}$ and 5.1 versus $2.4 \mathrm{ng} / 100 \mathrm{ml}$, respectively), whereas total $\mathrm{T} 3$ and free T3 (FT3) concentrations were higher in maternal than in fetal serum (74 versus $<18 \mathrm{ng} / 100 \mathrm{ml}$ and 176 versus $<90 \mathrm{pg} / 100 \mathrm{ml}$, respectively). Mean maximal thyroxine-binding globulin (TBG) binding capacity was higher in maternal than in fetal blood (16.5 versus $8.1 \mu \mathrm{g}$ T4/100 ml, respectively). Fetal serum was observed to contain a T4-binding $\alpha$-l-globulin, which probably is identical with fetuin, a glycoprotein unique to sera of fetuses and neonates of several species including the calf, foal, sheep, pig, and chick. Mean T4 clearance values were 0.614 and 0.107 liters $/ \mathrm{kg} / 24 \mathrm{hr}$, respectively, in fetal and maternal sheep and mean T3 clearance values were 8.52 versus 1.66 liters $/ \mathrm{kg} / 24 \mathrm{hr}$, respectively. Mean T4 turnover values were 46.1 and $5.59 \mu \mathrm{g} / \mathrm{kg} / 24 \mathrm{hr}$, and mean T3 turnover values were $<1.50$ and 1.22 $\mu \mathrm{g} / \mathrm{kg} / 24 \mathrm{hr}$ in fetal and maternal sheep, respectively. No placental transfer of $\mathrm{T} 4$ occurred and net maternal to fetal transfer of T3 amounted to only about $1 \%$ of total turnover of fetal thyronine.

These data confirm the autonomy of the fetal hypothalamic-pituitary-thyroid axis and they indicate that hormone utilization is much higher in fetal sheep (per kilogram body weight) than in maternal sheep. In addition, the higher T4/T3 serum concentration ratio and $\mathrm{T} 4 / \mathrm{T} 3$ turnover ratios in the fetus $(>471 / 1$ versus $74 / 1$ and $>31 / 1$ versus $4.6 / 1)$ indicate that the relative rates of $\mathrm{T} 3$ secretion and/or T3 conversion from T4 in peripheral tissues are less in fetal than in maternal sheep. Finally, the data indicate a poor correlation between free hormone concentrations and either hormone clearance or hormone turnover rates, which suggests tissue binding and/or metabolism are important determinants of thyroid hormone turnover in the fetus.
\end{abstract}

\section{Speculation}

The present data regarding thyroid hormone metabolism in fetal sheep are consistent with present evidence about thyroid hormone metabolism in the human fetus and suggest that the sheep can serve as a useful model for the human system. Furthermore, data in both species support the concept of autonomy of fetal thyroid function. The ob- 
servation of high $\mathrm{T} 4 / \mathrm{T} 3$ concentration and turnover ratios in the fetus was unexpected and might be explained on the basis of a high $\mathrm{T} 4 / \mathrm{T} 3$ secretion ratio, a low rate of conversion of $\mathrm{T} 4$ to $\mathrm{T} 3$, or a high rate of biliary $\mathrm{T} 4$ excretion in the fetal sheep.

\section{Introduction}

Recent data in man indicate that the fetal hypothalamic-pituitary thyroid axis functions autonomously of the maternal system. There is no correlation between total thyroid stimulating hormone $\mathrm{T} 4$, free thyroxine (FT4) or TSH concentrations in fetal or maternal serum at any time during gestation [9, 12, 13, 17]. Concentrations of T4 and FT4 in serum in fetuses at term usually exceed the respective maternal values [12, 17]. Fetal thyroidal autonomy has also been demonstrated in the sheep, in which species it has been demonstrated that TSH and T4 do not cross the placenta in significant quantities $[1,5,14]$. Moreover, in this species, $\mathrm{T} 4$ turnover in the fetus during the last trimester of pregnancy exceeds turnover of maternal $\mathrm{T} 4$ by about 8 times on a microgram per kilogram basis [5]. To characterize fetal thyroid hormone metabolism further in the sheep and to relate hormone turnover to free hormone concentrations, we have measured simultaneously $\mathrm{T} 4$ and $\mathrm{T} 3$ kinetics, total and free $\mathrm{T} 4$, total and free $\mathrm{T} 3$ concentrations, and binding capacities of thyroxine-binding proteins in maternal and fetal sheep during the third trimester of normal pregnancy.

\section{Materials and Methods}

One- to four-year-old Columbia and Columbia Suffolk sheep were obtained from a local source. Animals were maintained at an environmental temperature of $57-85^{\circ} \mathrm{F}$, were fed bailed alfalfa, and had free access to water. Uterotomies were performed with spinal anesthesia on ewes of 95- to 135-day gestation and indwelling exteriorized femoral artery catheters were placed in the fetuses. Jugular vein catheters were inserted into the dams to provide ready access to maternal blood. Blood specimens were drawn from the dam and fetus 48-96 hr after surgery for measurements of serum T4, T3, FT4, and FT3 concentrations and for assessment of the binding capacity of serum thyroid hormone-binding proteins. In one group of five animals, T4 kinetic studies were conducted using tracer hormones. ${ }^{125} \mathrm{I}$-labeled $\mathrm{T} 4$ and ${ }^{131} \mathrm{I}$-labeled $\mathrm{T} 4$ were injected into the dam and fetus, respectively, and serial blood specimens were drawn from each for periods of up to $96 \mathrm{hr}$. Potassium perchlorate $(400 \mathrm{mg}$ ) was administered orally to the dam twice daily to prevent iodide recycling. In the second group of six animals, T3 kinetic studies were obtained by a similar dual label protocol. The volume of distribution and halftime of plasma disappearance of $\mathrm{T} 4$ and $\mathrm{T} 3$ in the dam and fetus were estimated from these data. Placental hormone transfer was studied by counting ${ }^{125} \mathrm{I}$-labeled $\mathrm{T} 4$ or $\mathrm{T} 3$ in serum from the fetus after the dam had received injections, and ${ }^{131}$ I-labeled $\mathrm{T} 4$ or $\mathrm{T} 3$ in serum from the dam after the fetus had received injections.

All labeled isotopes were checked for iodide contamination by high voltage electrophoresis and they were discarded if inorganic iodide exceeded 2\%. Alkaliwashed butanol extracts of $250-\mu \mathrm{l}$ aliquots of each serum specimen were prepared in duplicate as described by Fisher et al. [11]. Specimens and standards were counted for ${ }^{131} \mathrm{I}$ and ${ }^{125} \mathrm{I}$ activities. From these data the disappearance of isotopes from plasma of dams and fetuses was determined. Data were recorded as percentage of injected dose per liter of plasma and were plotted semilogarithmically. From these plots the linear component of the disappearance curve was defined by the method of least squares and this was extrapolated to zero time. The volume of distribution $\left(V_{D}\right)$ of isotopes was calculated from the extrapolated zero time concentrations by the usual dilution formula. The half-time $\left(t_{1 / 2}\right)$ of hormone turnover was determined by least squares regression analysis of the linear portion of the disappearance curves. Hormone disappearance or clearance in liters/day was calculated as: clearance $($ liter $/ 24 \mathrm{hr})=\mathrm{V}_{\mathrm{D}}$ (liters) $\times 0.693 /\left[t_{1 / 2}\right.$ (24 hr)].

Details of the kinetic studies and estimates of hormone turnover have been published separately $[4,5]$.

Placental transfer of butanol-extractable radioactivity was measured as fetal-maternal and maternal-fetal placental clearance of labeled hormone assuming exchange between two hormone compartments (fetal and maternal) from which irreversible clearance is ongoing simultaneously. These computational methods have also been published [4].

Total T4 was measured by the protein-binding method of Murphy [15] and total T3 by the radioimmunoassay (RIA) procedure of Chopra et al. [2, 3]. Dialyzable T4 and T3 were measured by a modification of the method of Sterling and Brenner [18]. Serum 
Table I. Total thyroxine (T4), free thyroxine (FT4), and thyroxine-binding globulin (TBG) capacity in serum of maternal and fetal sheep

\begin{tabular}{|c|c|c|c|c|c|c|c|c|}
\hline \multirow[b]{2}{*}{ Sheep } & \multicolumn{4}{|c|}{ Maternal } & \multicolumn{4}{|c|}{ Fetal } \\
\hline & $\begin{array}{c}\mathrm{T} 4, \\
\mu \mathrm{g} / \\
100 \mathrm{ml}\end{array}$ & FT4, \% & $\begin{array}{c}\text { Absol- } \\
\text { ute } \\
\text { FT4, } \\
\text { ng/ } \\
100 \mathrm{ml}\end{array}$ & $\begin{array}{c}\mathrm{TBG}, \\
\mu \mathrm{g} / \\
100 \mathrm{ml}\end{array}$ & $\begin{array}{c}\mathrm{T} 4 \\
\mu \mathrm{g} / \\
100 \mathrm{ml}\end{array}$ & FT4, \% & $\begin{array}{c}\text { Absol- } \\
\text { ute } \\
\text { FT4, } \\
\text { ng/ } \\
100 \mathrm{ml}\end{array}$ & $\begin{array}{c}\mathrm{TBG}, \\
\mu \mathrm{g} / \\
100 \mathrm{mI}\end{array}$ \\
\hline 03 & 3.2 & 0.042 & 1.30 & 17.6 & 6.9 & 0.050 & 3.45 & 6.4 \\
\hline 04 & 6.2 & 0.059 & 3.65 & 12.8 & 8.7 & 0.076 & 6.60 & 5.8 \\
\hline 05 & 7.6 & 0.045 & 3.42 & 13.8 & 6.4 & 0.065 & 4.16 & 9.0 \\
\hline$E 6$ & 4.4 & 0.032 & 1.41 & 25.6 & 4.5 & 0.060 & 2.70 & \\
\hline 09 & 5.4 & 0.042 & 2.27 & 15.4 & 10.8 & 0.080 & 8.60 & 6.4 \\
\hline Mean & 5.36 & 0.044 & 2.4 & 17.0 & 7.5 & 0.066 & 5.1 & 6.9 \\
\hline SEM & 0.75 & 0.004 & 0.5 & 2.3 & 1.1 & 0.005 & 1.1 & 0.7 \\
\hline
\end{tabular}

Table II. Total triiodothyronine (T3), free triiodothyrone (FT3), and thyroxine-binding globulin (TBG) capacity in serum of maternal and fetal sheep

\begin{tabular}{|c|c|c|c|c|c|c|c|c|}
\hline \multirow[b]{2}{*}{ Sheep } & \multicolumn{4}{|c|}{ Maternal } & \multicolumn{4}{|c|}{ Fetal } \\
\hline & $\begin{array}{c}\mathrm{T} 3 \mathrm{RIA}, \\
\mathrm{ng} / \\
100 \mathrm{ml}\end{array}$ & FT3, \% & $\begin{array}{c}\text { Absol- } \\
\text { ute } \\
\text { FT3, } \\
\text { pg/ } \\
100 \mathrm{ml}\end{array}$ & $\begin{array}{c}\text { TBG, } \\
\mu \mathrm{g} / \\
100 \mathrm{ml}\end{array}$ & $\begin{array}{c}\text { T3 RIA, } \\
\text { ng/ } \\
100 \mathrm{ml}\end{array}$ & FT3, \% & $\begin{array}{c}\text { Absol- } \\
\text { ute } \\
\text { FT3, } \\
\text { pg/ } \\
100 \mathrm{ml}\end{array}$ & $\begin{array}{c}\text { TBG, } \\
\mu \mathrm{g}, \\
100 \mathrm{ml}\end{array}$ \\
\hline$O 23$ & 110 & 0.30 & 330 & 25 & 15 & 0.55 & 83 & 11.0 \\
\hline 024 & 98 & 0.13 & 127 & 15 & $<15$ & 0.39 & $<59$ & 8.0 \\
\hline 025 & 96 & 0.22 & 211 & 16.5 & $<15$ & 0.49 & $<74$ & 10.5 \\
\hline 026 & 56 & 0.19 & 106 & 15.5 & $<15$ & 0.61 & $<92$ & 7.5 \\
\hline 027 & 26 & 0.46 & 120 & 15.4 & $<15$ & 0.49 & $<74$ & 9.4 \\
\hline$O 28$ & 58 & 0.28 & 162 & 9.4 & 31 & 0.51 & 158 & 6.5 \\
\hline Mean & 74 & 0.263 & 176 & 16.1 & $<18$ & 0.506 & $<90$ & 8.8 \\
\hline SEM & 13.2 & 0.046 & 34.4 & 2.05 & $<2.7$ & 0.029 & $<14$ & 0.7 \\
\hline
\end{tabular}

1 RIA : Radioimmunoassay.

binding proteins were studied with reverse flow electrophoresis in a Beckman system [7]. Binding capacities were measured by loading sera with increasing quantities of $\mathrm{T} 4$ until saturation of binding proteins was assured.

\section{Results}

Data on total $\mathrm{T} 4$ and $\mathrm{T} 3$ and the binding capacities of TBG in the two groups of maternal and fetal pairs are presented in Tables I and II. The mean T4 concentration was higher in the fetuses than in the dams; whereas the mean $\mathrm{T} 3$ concentration was higher in the dams. The mean dialyzable T4 (Table I) also was significantly higher in the fetuses than in their dams $(0.066$ versus $0.044 \%, P<0.01)$ as was the absolute FT4 $(5.1 \mathrm{ng} / 100 \mathrm{ml}$ versus $2.4 \mathrm{ng} / 100 \mathrm{ml}, P<0.05$ ). Dialyzable T3 was higher in the fetuses (Table II) than in the dams $(0.506$ versus $0.263 \%, P<0.01)$, however, absolute FT3 levels were lower in the fetuses than in blood samples from the paired dams $(<90$ versus $176 \mathrm{pg} / 100 \mathrm{ml} P<0.05)$.

The mean maternal and fetal $\mathrm{T} 4$ binding capacities of TBG were 17.0 and $6.9 \mu \mathrm{g} / 100 \mathrm{ml}$, respectively, for animals from the $\mathrm{T} 4$ study and 16.1 and $8.8 \mu \mathrm{g} / 100$ $\mathrm{ml}$, respectively, for animals from the T3 study. There is no thyroxine-binding pre-albumin in the sheep and no estrogen hypersecretion to increase TBG levels during pregnancy. However, a T4-binding protein was observed in serum of fetal sheep that under electrophoresis moved ahead (anodal) of $\alpha$-1-globulin and behind albumin (see Fig. 1). We have referred to this T4 bind-

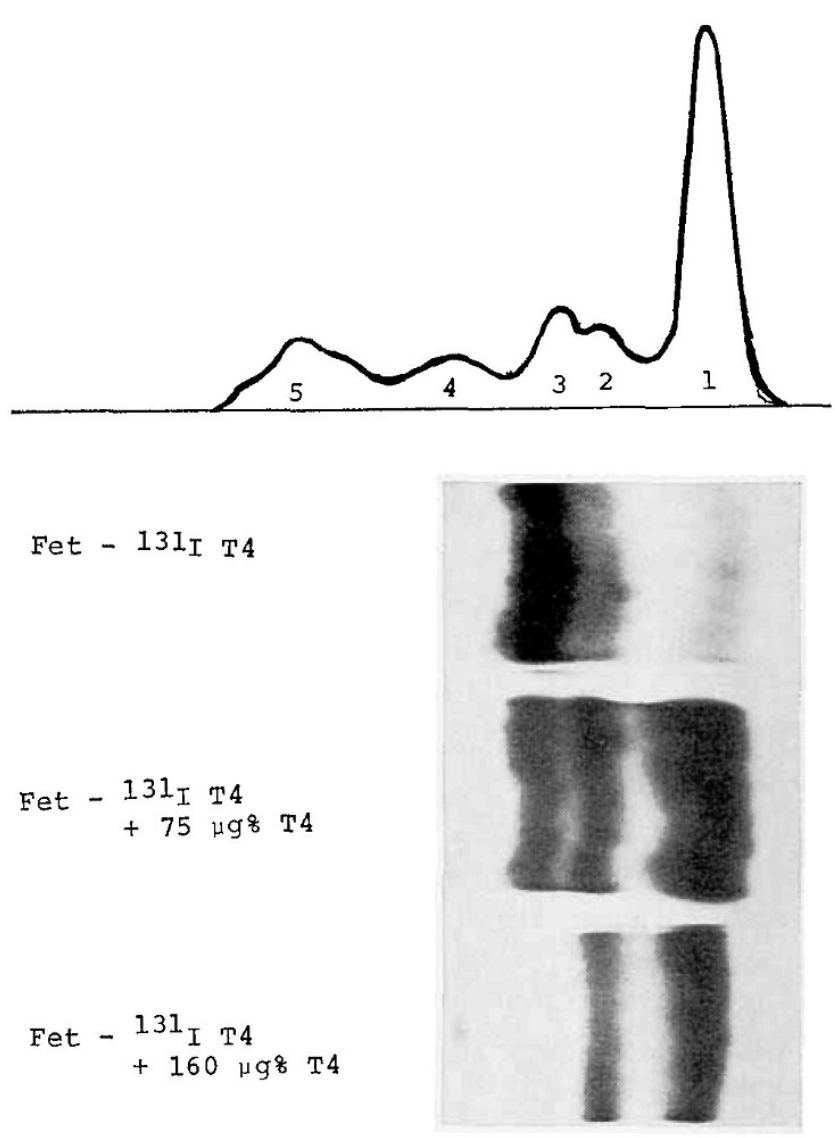

Fig. 1. Densitometer pattern and labeled thyroxine (T4) binding pattern in fetal sheep serum (130-day gestation). Peaks 1-5 represent albumin, fetuin, slow moving $\alpha$-1-globulin, $\alpha$-2-globulin, and $\beta$-globulin. There is little or no $\gamma$-globulin. The upper radioautogram was developed after electrophoresis of fetal serum with only tracer ${ }^{225}$-labeled $T 4$. Most of the radioactivity moves with inter- $\alpha$-globulin (TBG) and lesser amounts with fetuin and albumin. When the serum is loaded with $75 \mu \mathrm{g} / 100 \mathrm{ml}$ unlabeled T4, the T4 label is displaced from TBG to fetuin and albumin, but residual radioactivity is visible in the TBG area. When the serum is loaded with $160 \mu \mathrm{g} / 100 \mathrm{ml}$ unlabeled $\mathrm{T} 4$, radioactivity is visible only in the fetuin and albumin areas. 
ing protein as thyroxine binding fetal protein (TBFP) and preliminary studies indicate that it is, in fact, fetuin, an $\alpha$-l-glycoprotein unique to fetal and neonatal serum of several species, including the calf, foal, sheep, pig, and chick [10]. Fetuin has a molecular weight of about 50,000 [16]. The T4-binding affinity of fetuin is less than that of TBG and the maximal binding capacity is very high $(>600 \mu \mathrm{g} / 100 \mathrm{ml})$ [10]. The mean distribution of tracer ${ }^{125}$ I-labeled $\mathrm{T} 4$ among TBG, TBFP, and albumin measured during paper electrophoresis at $\mathrm{pH} 8.6$ in six paired sera from maternal and fetal sheep was: TBG 50\%, TBFP $17 \%$, and albumin $33 \%$. Thus, although TBFP-fetuin binds both $\mathrm{T} 4$ and $\mathrm{T} 3$, the dialyzable fractions of these hormones are greater in the fetus than in the dam. Moreover, absolute concentration of fetal FT4 is greater than the level of maternal FT4. Thus it seems that TBG is the major T4-binding protein in the fetus as it is in the adult sheep; TBFP, because of its lesser binding affinity, is of secondary importance.

Table III summarizes the $\mathrm{T} 4$ and $\mathrm{T} 3$ clearance data in the two groups of maternal-fetal pairs. Mean rates of clearance of T4 and T3 in liters $/ \mathrm{kg} / 24 \mathrm{hr}$, in the fetus exceed maternal clearance rates by five- to sixfold ( $\mathrm{T} 4=0.614$ versus 0.107 and $\mathrm{T} 3=8.52$ versus 1.66 ).

Table IV summarizes the mean clearance and mean hormone concentration data and includes mean rates of turnover of $\mathrm{T} 4$ and $\mathrm{T} 3$ in the dams and their fetuses. Mean rate of fetal turnover of $\mathrm{T} 4$ exceeds the maternal sheep turnover rate by eight- to ninefold (46.1 versus $5.59 \mu \mathrm{g} / \mathrm{kg} / 24 \mathrm{hr}$ ). Mean T3 turnover is either similar in fetus and dam or lower in fetal sheep $(<1.50$ versus $1.22 \mu \mathrm{g} / \mathrm{kg} / 24 \mathrm{hr}$ ) (Table IV).

\section{Discussion}

In the present study, total T4, percentage of dialyzable $\mathrm{T} 4$, and absolute free $\mathrm{T} 4$ concentrations were higher in fetal than in maternal serum. These findings are in agreement with those reported previously for the human fetus $[6,9,12,17]$. The difference in absolute free $\mathrm{T} 4$ is more marked in sheep because the $\mathrm{T} 4$ binding capacity of TBG is lower and the percentage of dialyzable $\mathrm{T} 4$ is higher in the sheep fetus than in the human fetus. Total concentrations of T3 and FT3 are higher in maternal than in fetal serum, even though the dialyzable T3 fraction is greater in the fetus than in the dam (Table II). Data on total T3 concentration are not yet available for the human fetus; earlier data [6] were obtained at term using a paper chromatographic method which is not reliable [8].
Table III. Iodothyronine clearance in maternal and fetal sheep

\begin{tabular}{|c|c|c|c|c|c|c|c|c|}
\hline \multirow{3}{*}{ Sheep } & \multicolumn{4}{|c|}{ Maternal clearance } & \multicolumn{4}{|c|}{ Fetal clearance } \\
\hline & \multicolumn{2}{|c|}{ Thyroxine } & \multicolumn{2}{|c|}{ Triiodothyronine } & \multicolumn{2}{|c|}{ Thyroxine } & \multicolumn{2}{|c|}{ Triiodothyronine } \\
\hline & $\begin{array}{l}\text { liters/ } \\
24 \mathrm{hr}\end{array}$ & $\begin{array}{l}\text { liters/ } \\
\mathrm{kg} / 24 \\
\mathrm{hr}\end{array}$ & $\begin{array}{l}\text { liter/ } \\
24 \mathrm{hr}\end{array}$ & $\begin{array}{l}\text { liters/ } \\
\mathrm{kg} / 24 \\
\mathrm{hr}\end{array}$ & $\begin{array}{l}\text { liters/ } \\
24 \mathrm{hr}\end{array}$ & $\begin{array}{c}\text { liters/ } \\
\mathrm{kg} / 24 \\
\mathrm{hr}\end{array}$ & $\begin{array}{l}\text { liters/ } \\
2+\mathrm{hr}\end{array}$ & $\begin{array}{l}\text { liters/ } \\
\mathrm{kg}\end{array}$ \\
\hline 03 & 6.24 & 0.106 & & & & & & \\
\hline 04 & 7.79 & 0.130 & & & 1.29 & 0.478 & & \\
\hline 05 & 3.47 & & & & 1.74 & 0.967 & & \\
\hline$E 6$ & 5.45 & 0.086 & & & 1.74 & 0.644 & & \\
\hline 09 & 5.78 & 0.105 & & & 1.54 & 0.367 & & \\
\hline 023 & & & 91.4 & 1.83 & & & 11.1 & 6.53 \\
\hline 024 & & & 73.3 & 1.55 & & & 13.7 & 9.13 \\
\hline 025 & & & 103.8 & 2.28 & & & 10.4 & 13.00 \\
\hline 026 & & & 66.6 & I. 38 & & & 15.2 & 6.61 \\
\hline 027 & & & 32.0 & 0.64 & & & 27.6 & 9.20 \\
\hline 028 & & & 103.8 & 2.28 & & & 16.6 & 6.64 \\
\hline Mean & 5.43 & 0.107 & 78.7 & 1.66 & 1.58 & 0.614 & 15.8 & 8.52 \\
\hline SEM & 0.65 & 0.009 & 11.2 & 0.25 & 0.10 & 0.130 & 2.56 & 1.03 \\
\hline
\end{tabular}

Table $I V$. Turnover of thyroxine (T4) and triiodothyronine (T3) in maternal and fetal sheep

\begin{tabular}{cccc}
\hline & $\begin{array}{c}\text { Mean clearance, } \\
\text { liters } / \mathrm{kg} / 24 \mathrm{hr}\end{array}$ & $\begin{array}{c}\text { Mean concentra- } \\
\text { tions, } \mu \mathrm{g} / \mathrm{liter}\end{array}$ & $\begin{array}{c}\text { Mean turnover, } \\
\mu \mathrm{g} / \mathrm{kg} / 24 \mathrm{hr}\end{array}$ \\
\hline Maternal & & & \\
T4 & 0.107 & 53.6 & 5.59 \\
T3 & 1.66 & 0.740 & 1.22 \\
Fetal & & & \\
T4 & 0.614 & 75.0 & 46.1 \\
T3 & 8.52 & $<0.18$ & $<1.50$ \\
\hline
\end{tabular}

The hormone turnover data (Table IV) were not corrected for placental transfer, since this is minimal in degree. No T4 transfer was detected in either the maternal to fetal (M-F) or the fetal to maternal (F-M) direction [5]. Some T3 transfer was observed, but it was minimal when compared with total fetal thyronine turnover [4]. Calculated F-M placental T3 clearance was 4.6 liters/24 hr [14], whereas total fetal T3 clearance was 15.8 liters/24 hr (Table III). Calculated M-F placental clearance was 3.56 liters/24 hr [4], whereas total maternal T3 clearance was 78.7 liters/24 hr (Table III). Calculated T3 transfer was $1.89 \mu \mathrm{g} / 24$ $\mathrm{hr}$ in the M-F direction and $0.83 \mu \mathrm{g} / 24 \mathrm{hr}$ in the F-M direction; net transfer was about $1 \mu \mathrm{g} / 24 \mathrm{hr}$ in the $\mathrm{M}-\mathrm{F}$ direction. Therefore, about $0.5 \mu \mathrm{g} T 3 / \mathrm{kg} / 24 \mathrm{hr}$ was contributed to the fetus, whereas total turnover of fetal hormone (T4 + T3, Table IV) was about 47 $\mu \mathrm{g} / \mathrm{kg} / 24 \mathrm{hr}$. These data support the autonomy of fetal hypothalamic-pituitary-thyroid function and they indicate that turnover of fetal hormone on the basis of body weight greatly exceeds maternal turnover.

Mean concentration of fetal serum $\mathrm{T} 3$ in the present study was much lower than the level of T3 in maternal 
serum (Table II); thus the T4/T3 concentration ratio in maternal serum was $74 / 1$, whereas, in fetal serum, the value was $<417 / 1$. The T4/T3 turnover ratios were $4.6 / 1$ and $>31 / 1$, respectively. Possible explanations for the low level of T3 in fetal serum and the high fetal T4/T3 turnover ratio include: (I) a relatively high $\mathrm{T} 4 / \mathrm{T} 3$ secretion ratio from the thyroid gland, (2) a relatively low rate of peripheral conversion of T4 to T3 and (3) a high rate of biliary $\mathrm{T} 4$ excretion by the fetus so that the $\mathrm{T} 4$ is not available for peripheral deiodination. Further studies are in progress to differentiate among these possibilities.

Finally, the present data indicate that disposal of $\mathrm{T} 4$ and T3 in the sheep correlates poorly with free hormone concentrations. An inverse correlation is seen between the T4-binding capacity of TBG and the percentage of dialyzable T4; mean TBG-binding capacity is lower in fetuses than in dams and the mean percentage of dialyzable $\mathrm{T} 4$ is higher (Table I). Thus, mean fetal clearance of $T 4$, as might be expected, is higher than mean maternal clearance of $\mathrm{T} 4$ (Table III). It cannot be concluded, however, that FT4 concentration is the major determinant of disposal of $\mathrm{T} 4$; although the mean concentration of FT4 in the fetus exceeds that in the dam twofold (Table I), mean fetal clearance of $\mathrm{T} 4$ exceeds mean maternal clearance of $\mathrm{T} 4$ fivefold (Table III) and mean fetal turnover of T4 exceeds mean maternal turnover of $\mathrm{T} 4$ eightfold (Table IV). The T3 data are even more disparate. Although the mean dialyzable T3 in the fetus is twice the maternal value, mean fetal clearance of $\mathrm{T} 3$ is 5 times mean maternal clearance of T3 (Table III), and mean fetal and maternal turnover of T3 are nearly comparable (Table IV). Presumably, tissue binding and/or metabolism are more important determinants of thyroid hormone turnover than are the free hormone concentrations.

\section{Summary}

Studies of T4 and T3 metabolism were conducted in fetal sheep during the last trimester of gestation. Stable hormone concentrations were measured by radioimmunoassay; free hormone concentrations were estimated by equilibrium dialysis. Maximal binding capacity of TBG was measured by reverse flow paper electrophoresis. Kinetic studies of $\mathrm{T} 3$ and $\mathrm{T} 4$ were conducted using radioiodine labeled hormones. Mean concentrations of T4 and free T4 were $7.5 \mu \mathrm{g} / 100 \mathrm{ml}$ and $5.1 \mathrm{ng} / 100 \mathrm{ml}$, respectively, in fetal serum and 5.4 . $\mu \mathrm{g} / 100 \mathrm{ml}$ and $2.4 \mathrm{ng} / 100 \mathrm{ml}$, respectively, in maternal serum. Mean concentrations of T3 and free T3 were
$<18 \mathrm{ng} / 100 \mathrm{ml}$ and $<90 \mathrm{pg} / 100 \mathrm{ml}$, respectively, in fetal serum and $74 \mathrm{ng}$ and $176 \mathrm{pg} / 100 \mathrm{ml}$, respectively, in maternal serum. The mean maximal T4-binding capacities of TBG in fetal and maternal sera were 8.1 and $16.5 \mu \mathrm{g} / 100 \mathrm{ml}$, respectively. In addition, labeled T4 binding was observed in the $\alpha$-1-globulin area in fetal serum during electrophoresis, which indicates the existence of a fetal T4-binding glycoprotein other than TBG. The significance of this protein in fetal $\mathrm{T} 4$ metabolism is not clear.

The $\mathrm{T} 4$ and $\mathrm{T} 3$ kinetic studies revealed mean metabolic clearance rates (MCR) in fetuses and dams for $\mathrm{T} 4$ of 0.62 and $0.1 \mathrm{l}$ liters $/ \mathrm{kg} / 24 \mathrm{hr}$, respectively, and of 8.5 and 1.7 liters $/ \mathrm{kg} / 24 \mathrm{hr}$, respectively, for T3. Finally mean turnover values were 46 and $5.6 \mu \mathrm{g} / \mathrm{kg} /$ $24 \mathrm{hr}$ for $\mathrm{T} 4$ and $<1.5$ and $1.2 \mu \mathrm{g} / \mathrm{kg} / 24 \mathrm{hr}$ for $\mathrm{T} 3$ in the fetuses and dams, respectively. Since little or no placental transfer of $\mathrm{T} 3$ or $\mathrm{T} 4$ occurred during these studies, we conclude that the fetal hypothalamic-pituitary-thyroid axis is functioning autonomously of the maternal system.

\section{References and Notes}

1. Comline, R. S., Nathanielsz, P. W., and Silver, M.: Passage of thyroxine across the placenta in the foetal sheep. Proc. Physiol. Soc. (London), 2: 3P (1969).

2. Chopra, I. J., AND LAM, R. W.: Use of 8-anilino-1-naphthalene-sulfonic acid (ANS) in radioimmunoassay of triiodothyronine in unextracted serum. Clin. Res., 20: 216 (1972).

3. Chopra, I. J., Solomon, D. H., and Beall, G. N.: Radioimmunoassay for measurement of triiodothyronine in human serum. J. Clin. Invest., 50: 2033 (1971).

4. Dussault, J. H., Hobel, C. J., Distefano, J. J., iII, Erenberg, A., AND Fisher, D. A.: Triiodothyronine turnover in maternal and fetal sheep. Endocrinology, 90: 1301 (1972).

5. Dussault, J. H., Hobel, C. J., And Fisher, D. A.: Maternal and fetal thyroxine secretion during pregnancy in the sheep. Endocrinology, 88: 47 (1971).

6. Dussault, J. H., Row, V. V., Lickrish, G., and Volpe, R.: Studies of serum triiodothyronine concentration in maternal and cord blood: transfer of triiodothyronine across the human placenta. J. Clin. Endocrinol. Metab., 29: 595 (1969).

7. Elzinga, K. E., Carr, E. A., JR., and Beierwaltes, W. H. Adaptation of the standard Durrum-type cell for reverse-flow paper electrophoresis. Amer. J. Clin. Pathol. (London), 36: 125 (1961).

8. Fisher, D. A., And Dussault, J. H.: Contribution of methodologic artifacts to the measurement of $\mathrm{T} 3$ concentration in serum. J. Clin. Endocrinol. Metab., 32: 675 (1971).

9. Fisher, D. A., Hobel, C. J., Garza, R., And Pierce, C.: Thyroid function in the pre-term fetus. Pediatrics, 46: 208 (1970).

10. FisHeR, D. A., AND LAM, R. W.: Thyroid hormone binding by a serum alpha globulin (fetuin) in the fetal sheep (in preparation).

11. Fisher, D. A., Morris, M. D., Lehman, H., and Lackey, C.: 
Studies of butanol extractable iodine by the ceric oxidation method. Anal. Biochem., 7: 37 (1964).

12. Fisher, D. A., Odell, W. D., and Hobel, C. J.: Thyroid function in the term fetus. Pediatrics, 44:526 (1969).

13. Greenderg, A. H., Czernichow, P., Reba, R. C., Tyson, J., AND Blizzard, R. M.: Observations on the maturation of thyroid function in early fetal life. J. Clin. Invest., 49: 2790 (1970).

14. Hopkins, P. S., And Thorburn, G. D.: Placental permeability to maternal thyroxine in the sheep. J. Endocrinol., 49: 549 (1971).

15. Murphy, B E. P., and Jachan, C.: The determination of thyroxine by competitive binding analysis employing an anion exchange resin and radiothyroxine. J. Lab. Clin. Med., 66: $161(1965)$.

16. Pedersen, K. O.: Ultracentrifugal electrophoretic studies on fetuin. J. Phys. Colloid Chem., 51: 164 (1947).
17. Robin, N. I., Refetoff, S., Fang, F., And Selenkow, H. A.: Parameters of thyroid function in maternal and cord serum at term pregnancy. J. Clin. Endocrinol., 29: I276 (1969).

18. Sterling, K., ANd Brenner, M. A.: Free thyroxine in human serum: simplified measurement with the aid of magnesium precipitation. J. Clin. Invest., 45: 153 (1966).

19. The present address of Dr. J. H. Dussault is: Department of Medecine Nucleaire, Centre Hospitalier Université Laval, 2705 Boulevard Laurier, Quebec 10, P.Q., Canada.

20. This work was supported by United States Public Health Service Grant no. AM04270 from the National Institute of Arthritis and Metabolic Diseases, National Institutes of Health.

21. Requests for reprints should be addressed to: D. A. Fisher, M.D., Division of Endocrinology, Harbor General Hospital, 1000 West Carson Street, Torrance, Calif. 90509 (USA).

22. Accepted for publication August 9, 1972. 